Original Research Paper

\title{
Penerapan Hasil Pengembangan Media Pembelajaran Berbasis Aplikasi Youtube Terintegrasi 5M untuk Meningkatkan Kemampuan Argumentasi Ilmiah Peserta Didik Kelas X pada Materi Ajar Ekosistem di SMAN 1 Mataram
}

\author{
Devi Ayu Septiani ${ }^{1}$, Irmayani ${ }^{1,2 *}$, Yufika Dewi Muksin ${ }^{1}$ \\ ${ }^{1}$ Program Studi Pascasarjana Pendidikan IPA, Universitas Mataram, Mataram,Indonesia \\ ${ }^{2}$ Guru Biologi, SMAN 1 Mataram, Mataram, Indonesia
}

https://doi.org/10.29303/jpmpi.v3i2.669

Sitasi: Septiani, D., Irmayani., \& Muksin, Y. D. (2021). Penerapan Hasil Pengembangan Media Pembelajaran Berbasis Aplikasi Youtube Terintegrasi 5M untuk Meningkatkan Kemampuan Argumentasi Ilmiah Peserta Didik Kelas X pada Materi Ajar Ekosistem di SMAN 1 Mataram. Jurnal Pengabdian Magister Pendidikan IPA, 4(1)

\section{Article history}

Received: 03 Februari 2021

Revised: 08 Maret 2021

Accepted: 06 April 2021

*Corresponding Author: Irmayani, Program Studi Pascasarjana Pendidikan IPA, Universitas Mataram, Mataram, Indonesia;

Email: irmay5862@gmail.com

\begin{abstract}
Media merupakan segala sesuatu yang dapat dijadikan sebagai perantara untuk menyampaikan informasi dari pemberi informasi kepada penerima informasi, kaitannya dengan kegiatan pembelajaran yakni dari pendidik kepada peserta didik. Penggunaan media belajar berupa video dalam proses pembelajaran akan membuat otak peserta didik menjadi lebih segar karena salah satu hal yang disukai peserta didik adalah menonton. Salah satu aplikasi tontonan yang cukup digemari dan menjadi salah satu sumber informasi adalah YouTube. Sehingga tujuan kegiatan pengabdian yang akan dilakukan adalah penerapan dari hasil pengembangan media pembelajaran berbasis aplikasi youtube terintegrasi $5 \mathrm{M}$ yang dapat meningkatkan kemampuan argumentasi ilmiah peserta didik. Kemampuan argumentasi ilmiah penting dimiliki peserta didik dalam mengambil keputusan, dimana kemampuan ini merupakan bekal yang akan sangat bermanfaat dalam perkembangan abad ke-21. Adapun terintegrasi 5M ini merupakan proses mengamati, menanya, mengumpulkan informasi, menalar dan mengkomunikasikan yang dimana tahapan ini terintegrasi dalam pengembangan media aplikasi youtube yang dikembangkan. Kegiatan pengabdian ini dilaksanakan secara daring (online) di SMAN 1 Mataram. Hasil menunjukkan bahwa adanya peningkatan kemampuan argumentasi ilmiah terhadap penerapan dari pengembangan media pembelajaran berbasis aplikasi youtube terintegrasi $5 \mathrm{M}$, hal ini dibuktikan dengan keaktifan peserta didik dalam proses pembelajaran dan dari jawaban hasil post test yang menunjukkan alasan-alasan peserta didik dalam memberikan keputusan atas jawaban yang telah dipilih.
\end{abstract}

Keywords: Media Pembelajaran, Aplikasi Youtube Terintegrasi 5M, Kemampuan Argumentasi Ilmiah

materi ajar yang dipilih adalah materi yang menurut pengelola pendidikan terbukti telah memberikan manfaat bagi masa depan anak didik dan masyarakat. Urutan materi tersebut kemudian dipilih dan disusun secara sistematis dan logis.

Kurikulum sebagai pedoman pendidikan bertujuan untuk menghasilkan output yang dibutuhkan, terutama untuk generasi yang akan menempuh pendidikan ke tingkat yang lebih tinggi. Hal ini berhubungan dengan makna pendidikan yang tertuang dalam UU No. 20 Tahun 2003 yakni 
usaha sadar dan terencana untuk mewujudkan suasana belajar dan proses pembelajaran agar peserta didik secara aktif mengembangkan potensi dirinya untuk memiliki kekuatan spiritual keagamaan,pengendalian diri, kepribadian, kecerdasan, akhlak mulia, serta keterampilan yang diperlukan dirinya, masyarakat, bangsa, dan negara. Senada dengan tujuan pendidikan nasional dalam undang-undang No. 20 tahun 2003 yaitu, pendidikan diupayakan dengan berawal dari manusia apa adanya (aktualisasi) dengan mempertimbangkan berbagai kemungkinan yang apa adanya (potensialitas), dan diarahkan menuju terwujudnya manusia yang seharusnya atau manusia yang dicita-citakan (idealitas). Dengan kata lain, tujuan pendidikan yakni manusia yang beriman dan bertaqwa kapada Tuhan YME, berakhlak mulia, sehat, cerdas, berperasaan, berkemauan, dan mampu berkarya; mampu memenuhi berbagai kebutuhan secara wajar, mampu mngendalikan hawa nafsunya; berkepribadian, bermasyarakat dan berbudaya (Sujana, 2019).

Pandemi Covid-19 saat ini telah memporakpondakan hampir seluruh sendi kehidupan termasuk dunia pendidikan. Berjalannya dunia pendidikan sekarang ini tidak lagi sama dengan masa-masa sebelumnya. Banyak hal yang berubah, mulai dari tempat belajar yang harus di rumah saja, cara belajar yang tadinya bisa tatap muka sekarang lebih banyak dalam jaringan internet. Metode belajar yang awalnya tidak terpikirkan menggunakan metode yang dapat diakses dengan jaringan, sekarang ini banyak dimodifikasi agar materi bisa tersampaikan melalui metode yang dapat dengan mudah diakses peserta didik di rumah.

Dari hasil studi kasus yang telah dilaksanakan sejak tanggal 28 Oktober 2020 hingga 01 September 2020, penulis menemukan bahwa salah satu faktor penghambat kurikulum ada pada implementasi pembelajaran yakni kesiapan peserta didik dan motivasi belajar peserta didik yang tidak selamanya baik. Penggunaan bahan ajar dan metode yang monoton dapat membuat peserta didik cepat bosan. Kebosanan tersebut semakin menjadi di masa pandemi ini, terutama jika guru hanya membagikan materi dan tugas kepada peserta didik tanpa mencoba inovasi lain yang dapat memancing semangat belajar peserta didik. Di sisi lain, kemampuan argumentasi ilmiah peserta didik masih perlu untuk ditingkatkan. Sebagai contoh, ketika menentukan suatu jawaban terhadap suatu soal pilihan ganda, seringkali peserta didik tidak dapat mendeskripsikan alasan ilmiah atas jawaban yang mereka pilih.

Oleh karena itu dibutuhkan media yang dapat menstimulasi semangat belajar peserta didik serta menstimulasi kemampuan berpikir peserta didik. Falahudin (2014) menuliskan bahwa makna umum dari kata media adalah segala sesuatu yang dapat menyalurkan informasi dari sumber informasi kepada penerima informasi. Dalam arti sempit, media pengajaran hanya meliputi media yang dapat digunakan secara efektif dalam proses pengajaran yang terencana, sedangkan dalam artian luas, media tidak hanya meliputi media komunikasi elektronik yang kompleks, tetapi juga mencakup alat-alat sederhana, seperti slide, fotografi, diagram, dan bagan buatan guru, objek-objek nyata, serta kunjungan ke luar sekolah (Muhson, 2010). Dengan demikian dapat diartikan bahwa media merupakan segala sesuatu yang dapat dijadikan sebagai perantara untuk menyampaikan informasi dari pemberi informasi kepada penerima informasi, kaitannya dengan kegiatan pembelajaran yakni dari pendidik kepada peserta didik.

Pada bulan Desember 2020, penulis telah mengembangkan media pembelajaran berupa video pembelajaran berbasis aplikasi youtube terintegrasi 5 M. Pradikta (2015) menuliskan bahwa YouTube merupakan kondisi rancangan, pemikiran ataupun rencana dasar sebuah situs yang menyediakan layanan berbagi informasi dalam bentuk video dan dapat dinikmati langsung oleh para pengunjungnya. Media pembelajaran yang telah dikembangkan tersebut mendapat respon yang positif dari para responden. Dengan demikian, penulis merasa hal ini perlu diaplikasikan sesering mungkin sehingga peserta didik dapat memperoleh kembali PAIKEM (Pembelajaran Aktif, Inovatif, Kreatif, Efektif, dan Menyenangkan) dan meningkatkan kemampuan argumentasi ilmiahnya.

\section{Metode}

a. Persiapan

Tahap persiapan dalam pengabdian ini meliputi;

1. Persiapan perangkat pembelajaran yang meliputi RPP dan instrument penelitian. 
2. Pembuatan Video Pembelajaran berbasis aplikasi Youtube terintegrasi 5M (Mengamati, Menanya, Mengumpulkan, Mengasosiasikan, Mengkomunikasikan).

3. Persiapan aplikasi zoom meeting sebagai sarana pembelajaran daring

b. Media Pembelajaran

1. Video Youtube Link Video: https://youtu.be/wpn_kzzxrAg Nama Akun Youtube: Inkma_Bio

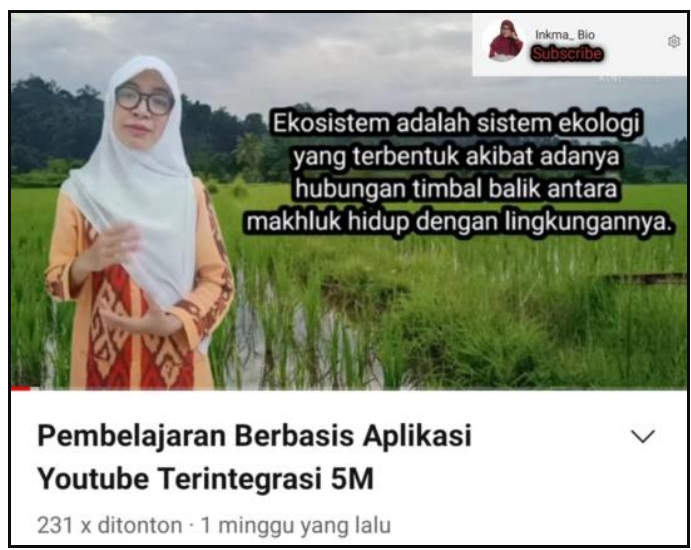

Gambar 1. Tampilan Video Youtube

2. Metode Pembelajaran

Metode pembelajaran yang dikembangkan dalam media pembelajaran berbasis aplikasi youtube adalah terintegrasi 5M. Adapun tahapan 5M dalam pendekatan saintifik tersebut merupakan proses mengamati, menanya, mengumpulkan informasi, mengasosiasi dan mengkomunikasikan (Perdata, 2016).

c. Pelaksanaan

Tahap pelaksanaan dalam kegiatan ini sebagai berikut;

1. Mengirimkan link zoom meeting kepada peserta didik dan tim pengabdian.

2. Memberikan pretest kepada peserta didik. Adapun pretest diberikan di awal pembelajaran dalam bentuk google form. Waktu pengerjaan adalah 10 menit.

3. Penerapan pembelajaran dengan aplikasi YouTube terintegrasi 5M. Pada tahap ini, tim pengabdi akan mengajarkan materi ekosistem dengan tekhnik yang diharapkan menciptakan suasana PAIKEM.

4. Memberikan posttest kepada peserta didik. Posttest diberikan 10 menit sebelum jam pelajaran berakhir. Posttest diberikan dalam bentuk google form.

5. Analisis data. Tahap ini dilakukan setelah semua jawaban peserta didik didownload.

\section{Hasil dan Pembahasan}

Perkembangan ilmu pengetahuan dan tekhnologi tentunya menjadi sebuah tantangan bagi umat manusia. Jika kita menyoroti dunia pendidikan saat ini, peran teknologi begitu penting sehingga guru perlu melek tekhnologi agar tidak tertinggal oleh para peserta didiknya. Pendidikan yang baik adalah pendidikan yang mempersiapkan peserta didik mengembangkan diri mereka sehingga memiliki potensi-potensi yang kelak berperan dalam membangun bangsa tersebut. untuk mencapai hal tersebut, guru perlu membuat terobosan-terobosan baru yang sesuai dengan karakteristik peserta didik kekinian yang dapat dikatakan cukup melek teknologi.

Penggunaan media belajar berupa video dalam proses pembelajaran akan membuat otak peserta didik menjadi lebih segar karena salah satu hal yang disukai peserta didik adalah menonton. Pengemasan video pembelajaran menjadi tontonan menarik merupakan tantangan bagi guru. Video tersebut juga akan membantu anak-anak semakin memahami bahwa apa yang mereka pelajari di kelas juga dekat dengan kehidupan mereka seharihari sehingga pembelajaran tidak hanya terhenti di kelas, tapi akan berlangsung saat mereka di rumah atau di tempat-tempat lain. Salah satu aplikasi yang cukup digemari dan menjadi salah satu sumber informasi adalah YouTube. youtube bisa menjadi sumber belajar dan media pembelajaran yang bisa memenuhi tuntutan kebutuhan generasi digital. Youtube bisa meningkatkan minat dan mendukung gaya belajar generasi digital. Youtube juga dikatakan dapat memberikan pengalaman pembelajaran dengan teknologi baru yang akan berguna saat mereka lulus (Burke, Snyder, \& Rager, 2009). Selain itu Youtube juga menyediakan ratusan ribu video dengan berbagai ragam topic yang bisa diintegrasikan dalam pembelajaran di kelas. Youtube juga akan menjadi perpustakaan video gratis yang sangat luas bagi pembelajar yang akan mendorong mereka menjadi pembelajar yang mandiri.

Oleh karena itu penulis membuat inovasi baru dengan memanfaatkan aplikasi youtube untuk 
meningkatkan argumentasi ilmiah melalui pemberian film edukasi bagi peserta didik (Farhatunnisya, 2020). Kemampuan argumentasi ilmiah ini penting dimiliki peserta didik sehingga peserta didik mempunyai kemampuan dalam mengambil keputusan (Riwayani et al.2019). Kemampuan ini merupakan bekal yang akan sangat bermanfaat dalam perkembangan abad ke- 21 .

Proses mengamati, menanya, mengumpulkan informasi/mencoba, menalar/mengasosiasi, mengkomunikasikan merupakan tahapan dalam pendekatan saintifik (Perdata, 2016). Proses-proses tersebut meruapakan aktivitas yang mampu memicu kemampuan berpikir anak sehingga mampu melahirkan argumen-argumen ilmiah. Prosesproses tersebut dapat dikembangkan oleh anak didik dalam proses pembelajaran di kelas maupun di lingkungan sekitar rumah dan tempat-tempat lainnya.

Pengabdian ini dilakukan dengan cara penerapan di dalam kelas secara daring (online) melalui media zoom meeting kepada peserta didik kelas X SMAN 1 Mataram. Adapun pada sesi pertama yaitu proses pengenalan dengan penyampain tentang apa itu kemampuan argumentasi ilmiah, pentingnya memiliki kemampuan argumentasi ilmiah dan manfaat media pembelajaran salah satunya media aplikasi Youtube bagi dunia pendidikan. Sesi berikutnya adalah proses pembelajaran untuk materi ekosistem dengan menampilkan video youtube kepada peserta didik. Dimana sebelum proses pembelajaran peserta didik diarahkan untuk mengerjakan pretest dan kemudian setelah kegiatan pembelajaran dengan bantuan media pembelajaran berbasis youtube terintegrasi $5 \mathrm{M}$ peserta didik juga diberikan posttest.

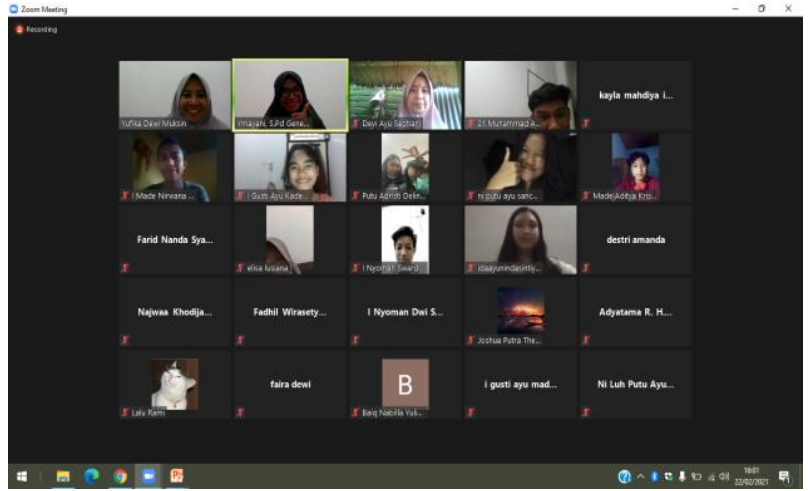

Gambar 2. Kegiatan Belajar Mengajar dalam Penerapan Media Pembelajaran Berbasis Youtube
Terintegrasi 5M untuk Meningkatkan Kemampuan Argumentasi Ilmiah di kelas X SMAN 1 Mataram

Berdasarkan nilai pretest dan posttest, kelas yang digunakan sebagai sampel penelitian, peserta didiknya mengalami peningkatan kemampuan argumentasi ilmiah. Ini menunjukkan konsistensi peningkatan kemampuan argumentasi ilmiah peserta didik setelah diterapkan pembelajaran dengan menggunakan media pembelajaran berbasis youtube terintegrasi $5 \mathrm{M}$ pada materi ekosistem untuk peserta didik kelas X di SMAN 1 Mataram Selain itu, kemampuan argumentasi ilmiah peserta didik saat kegiatan belajar mengajar juga dinilai. Peningkatan kemampuan argumentasi ilmiah peserta didik secara verbal saat kegiatan pembelajaran pada semua kategori kecuali kategori memberikan gagasan (claim). Hanya kategori memberikan gagasan (claim) dan memberikan dukungan (backing) yang rasional sajalah yang terjadi peningkatan. Namun secara keseluruhan terjadi peningkatan kemampuan agumentasi ilmiah peserta didik secara verbal saat kegiatan belajar mengajar yang diperoleh peserta didik. Hal ini juga berlaku untuk kemampuan argumentasi ilmiah tertulis peserta didik dalam menjawab soal posttest.

Sehingga hasil pengabdian setelah dilakukan penerapan media pembelajaran berbasis aplikasi youtube terintegrasi $5 \mathrm{M}$ untuk meningkatkan kemampuan argumentasi ilmiah menunjukkan bahwa adanya peningkatan kemampuan argumentasi ilmiah peserta didik. Dimana sebelum penerapan video pembelajaran kemampuan argumentasi anak-anak masih belum mencapai standar. Argumentasi yang berupa alasan memilih suatu jawaban pada soal pilihan ganda belum dapat dikatakan sebagai argumentasi ilmiah. Komponen argumentasi ilmiah meliputi claim, evidence, warrant, backing, qualifier, dan rebuttal (Chan \& Ester, 2010). Selain itu anak-anak juga tidak interaktif dalam proses pembelajaran. Setelah penerapan video pembelajaran berbasis aplikasi youtube terintegrasi $5 \mathrm{M}$, tampak keaktifan peserta didik dalam proses pembelajaran. Di samping itu, alasan-alasan peserta didik memilih jawaban pada soal pilihan ganda menunjukkan adanya peningkatan kemampuan argumentasi ilmiah. 


\section{Kesimpulan}

Berdasarkan hasil kegiatan pengabdian dapat disimpulkan bahwa media pembelajaran berbasis aplikasi youtube terintegrasi $5 \mathrm{M}$ dapat meningkatkan kemampuan argumentasi ilmiah peserta didik kelas X pada materi ajar ekosistem di SMAN 1 Mataram. Adapun peningkatan ini tampak pada keaktifan peserta didik dalam proses pembelajaran dan dari jawaban hasil post test yang menunjukkan alasan-alasan peserta didik dalam memberikan keputusan atas jawaban yang telah dipilih. Sehingga pengembangan media ajar berbasis aplikasi youtube terintegrasi $5 \mathrm{M}$ ini dapat meningkatkan kemampuan argumentasi ilmiah peserta didik.

\section{Ucapan Terima Kasih}

Penulis mengucapkan terima kasih kepada Drs. Dr. Abdul Syukur, M.Si dan Dr. Jamaludin, M.Pd selaku dosen mata kuliah studi mandiri yang telah membimbing kami dalam proses pelaksanaan penyusunan artikel dari kegiatan pengabdian di SMAN 1 Mataram dan terimakasih kepada pihak yang terlibat serta memberi dukungan atas terlaksananya kegiatan pengabdian di SMAN 1 Mataram.

\section{Daftar Pustaka}

Burke, S.C., Snyder, S., Rager, R.C. 2009. An Assessment of Faculty Usage of Youtube as a Teaching Resource. The Internet Journal of Allied Health Sciences and Practice. Vol. 7 No. 1, available online at http://ijahsp.nova.edu

Falahuddin, A. 2014. Pemanfaatan Media dalam Pembelajaran. Lokakarya Regional Ikatan Widyaiswara Indonesia (IWI) Provinsi Banten, 1(4), 104-117.

Farhatunnisya, A. 2020. Pemanfaatan Video YouTube dalam Meningkatkan Motivasi Belajar Siswa Insan Litera. Jurnal Com_Edu, 3(2), 109-114.

Muhammad, I. 2013. Diferensiasi Makna Kurikulum di Indonesia. Jurnal Mudarrisuna, 3 (2), 282-294.

Muhson, A. 2010. Pengembangan Media Pembelajaran Berbasis Teknologi Informasi.
Jurnal Pendidikan Akuntansi Indonesia, 8(2), $1-10$.

Perdata, KBI. 2016. Instrumen Observasi Kegiatan Inti Pembelajaran Matematika Berbasis Pendekatan Saintifik (5M) di SMA. Jurnal Santiaji Pendidikan, 6(2), 126-147.

Pradikta, R. 2015. Aplikasi Video Pembelajaran dengan Konsep Youtube. SATIN - Sains dan Teknologi Informasi, 1 (1), 20-27.

Riwayani, R. et al. 2019. Analisis Kemampuan Argumentasi Ilmiah Siswa pada Materi Optik: Problem Based Learning Berbantuan Edu_Media Simulation. Junrla Inovasi Pendidikan IPA, 5(1), 45-53.

Sujana, I.W.C. 2019. Fungsi Dan Tujuan Pendidikan Indonesia. Jurnal Pendidikan Dasar 4(1), 29-39.

Undang-Undang Republik Indonesia No. 20 Tahun 2003 tentang Standar Pendidikan Nasional. 